\title{
Humour and enjoyment reducers in cinema and theatre comedy
}

\author{
Arie Sover \\ Ashkelon Academic College, Israel
}

\begin{abstract}
In this research, I am trying to define a new concept which I shall call Enjoyment Reducer, referring to verbal or visual content, incorporated into comic situations, which may offend or disturb the viewer's enjoyment. There are comic situations that are only partially enjoyable and, at times, even cause embarrassment to the point of adversely affecting our enjoyment. These types of comic situations include what I term Enjoyment Reducers since they operate contrary to the function for which the comic situations were intended, which is to cause the viewer enjoyment. It should be noted that practically every comic situation includes Enjoyment Reducers because they are based on incongruities which disrupt our normal order or values. The fact that we laugh at humorous situations means that their enjoyable effect is stronger than the Enjoyment Reducers' effect. Additionally, Enjoyment Reducers are both culture-dependent and contingent upon the viewer's personality traits. Therefore, what one person perceives as an Enjoyment Reducer might be understood differently by another. The research findings reveal various types of Enjoyment Reducers that relate to human values, prohibitions and taboos. In addition, I will refer to another concept that is quite known, Enjoyment Enhancers, which might shed light on the main focus of the present research, which is Enjoyment Reducers. This research focuses mainly on comedy film, although the results are also relevant to theatre and all types of comic shows.
\end{abstract}

Key words: comedy; cinema; theatre; humour; taboo; enjoyment.

\section{Introduction}

In this research, I suggest that there are comic situations that are only partially enjoyable and, at times, even cause embarrassment to the point of adversely affecting our enjoyment. Comic situations that breach norms and values, and even break certain taboos are liable to arouse 
negative feelings. It is these types of comic situations that include what I term Enjoyment Reducers since they operate contrary to their main goal, which is to cause the viewer to enjoy the comic situation (on laughter and enjoyment, see Morreall 2009: 41-58).

When creating comic situations, the author or comedian tends to consciously or unconsciously consider cultural values within the permissible and forbidden of the audience. Nevertheless, it turns out that reactions to comic situations on a personal level are diverse from complete acceptance to total rejection. The comic creator operates within a particular cultural framework, that is why we can see that many funny situations (gags) in various comedy films recur in one form or another (Sover 2009: 99).

It is important to note at this point that what I refer to as Enjoyment Reducers may be perceived that way by a specific person, whereas the perception by someone else may be different altogether. In other words, this research does not engage in a fixed mathematical formula which works in any situation for all people. However, comedy and the comic, like humour in general, are also relative rather than definite. What makes me laugh may not make the other laugh, and what one considers comic may be seen by others as offensive.

\section{Enjoyment and culture values}

Pleasure is a central theme in theories of entertainment (Tamborini et al. 2010). Some researchers describe enjoyment as the satisfaction of personal needs not necessarily in the field of enjoyment itself, but rather for the purpose of satisfying cognitive or emotional needs (Katz et al. 1973; 1974; Reiss \& Wiltz 2004; Triezenberg 2004). Others regard enjoyment as a result of strengthening basic values or morality. Viewers want to see the good rewarded and the evil punished (Zillmann 2000; Ravi 2008). Some researchers claim that consumers of all genres of media consciously or subconsciously choose media texts which reflect their values and strengthen their belonging to certain social groups (Hay 2001; Hall 2007; Waldron 2006; Pop 2012). Comedy is the most popular entertainment genre amongst media consumers (Zillmann 2000).

Taboo, according to Freud, represents two dialectic directions - that of the "sacred" or "consecrated" and that of the "dangerous", "forbidden" or "unclean" (Freud 1965: 29). The taboo is part of a system of basic rules that helps in the organisation of the social order and is essentially meant to protect the life of the individual and society. Breaking a taboo is in essence a symbolic or actual blow to the moral or social principles accepted by the community as a whole. Ignoring or flagrantly disobeying a prohibition or a taboo is considered to negatively affect the person committing the misdemeanour (Cazaneuve 1971: 33; Israeli General Encyclopaedia 1990: 125).

In the 19th and early 20th century, the Japanese thought there were comic situations in Moliere's plays which portrayed the father as a ridiculous character. Therefore, for a long period they objected to the translation of Moliere's plays into Japanese, on the grounds that this would undermine parental authority (Lallo 1940: 200).

Spinoza (1967: 158-160) argues that, if something makes us feel joy and, at the same time, makes us feel sadness, we love it and hate it at the same time. This situation emerging from two conflicting feelings is called confusion of mind.

Swabey (1970: 247) argues that when there are conflicting values in comedy, the negative side can never overpower its positive aspects. Therefore, we need to enable irony and satire to do their evils because there is still the beauty of the comic spirit and the serenity of humour. It appears that the idea that humorous situations include conflicting feelings or 
values, contradicts Bergson's (2009: 25-26) idea that in humorous situations the emotions are uninvolved.

\section{Research method}

The research method is based upon the analysis of comic situations in forty three comedy films. The analysis focuses on the content and structure of the comic situations, discerning the Enjoyment Reducers in each. Examples are mainly taken from the films of Charlie Chaplin, Laurel and Hardy, Louis de Funès, Woody Allen, Mel Brooks, and Monty Python, who invented, among many others, the comic language of comedy films (on the data examined, see the list at the end of the paper). To clarify the notion of Enjoyment Reducers, I have chosen comic situations which include significant order disruptions or, as I call them, Enjoyment Reducers. It has to be noted that the research does not intend to analyze a specific film or creator, but to shed light on a new notion, that is the Enjoyment Reducer.

\subsection{Research limitations}

The selection of humorous situations and Enjoyment Reducers is made by me. I assume that they are appropriate to a potential group of comedy viewers but not to all. Therefore, when I mention the viewers in this study I refer to a virtual group of viewers.

\section{Findings}

It can be said that every comic situation consists of a mixture of contradicting emotions: enjoyment, on the one hand, and Enjoyment Reducers, on the other. Since humour is based on unusual or incongruous situations (Shultz 1972; Raskin 1985: 106; Forabosco 1992), and since each of the unusual situations contains an anti-normative, order-disrupting element, it generates stress, anxiety or fear, depending on the type and extent of deviation from the norm, which are relieved with laughter (Spencer 1911: 302; Kuiper et al. 1993; Lothane 2008). Therefore, comic situations contain inherent Enjoyment Reducers. The extent of disrupting the order or deviation may be limited and subconscious. In such cases, the level of enjoyment by far exceeds the level of fear or anxiety. Comic situations, such as the wind blowing the hat off a person's head or someone falling off a broken chair, are order-disrupting situations. Their degree of disruption is usually seen - not by everyone- as limited and, therefore, laughter at the sight of these circumstances generates great amusement. However, a person talking to him/herself out loud in the street may cause people watching him/her to laugh, but these laughs are accompanied by a feeling of anxiety.

Relevant examples result from Mel Brooks' tendency to use comic situations which combine humour and Enjoyment Reducers. In his film Young Frankenstein (1974), he shaped the monstrous, frightening figure of Frankenstein, and, in his film Silent Movie (1976), he shaped the head of the "Engulf \& Devour" conglomerate as a sort of vampire who, in his anger, spews foam and produces bark sounds. These two characters represent great abnormality that reminds the audience of horror films, which by nature may generate tension and anxiety. In High Anxiety (1977), Brooks gets off an airplane and walks into the terminal. Suddenly, he sees a woman running towards him screaming. Brooks, frightened and baffled, 
covers his face with his hands. The woman comes running towards him; she runs past him and hugs a man standing behind him. This is definitely a comic situation, but it is charged with uncertainty and anxiety. In another film, The Twelve Chairs (1970), Brooks has a fit after Father Fyodor is unable to find the treasure hidden in one of the chairs. He cries and laughs alternately. Despite being comic, these situations contain a good number of Enjoyment Reducers: conflicting emotions can be found in the same humorous situation and still be funny. That is why I argue that Bergson's (2009) idea that one can laugh at a comic situation only if his/her emotions are anesthetised is wrong.

\subsection{Sexual humour}

Explicit sex is one of the Enjoyment Reducers. Film comedy does not tend to use explicit sexual content. As its main role is to draw as much happiness as possible, incorporating in comedy a topic which touches upon people's inhibitions and lack of confidence is like adding salt to something that should be sweet. Therefore, film comedy is not inclined to use such material. Nevertheless, use of explicit sexual content is made on occasion. For instance, Gene Wilder uses a method of sexual seduction in stages when he investigates a beautiful girl and tries to get her important confession. At each stage of the investigation he takes off some of his clothes. Additionally, he caresses and kisses her. This investigation should parallel and parody a police investigation, but Gene Wilder aims at a sexual questioning which could be a good opening for a pornographic film. The emotional experience of watching a pornographic film is nothing like the emotional experience of watching a comedy film. The combination harms the experience of enjoying the comic situation (The Adventure of Sherlock Holmes' Smarter Brother 1975). An additional example of using an enjoyment reducing sexual motif can be found in Monty Python's Meaning of Life (1983), where in one scene we see a sex education lesson with demonstrations by the teacher and his wife.

Woody Allen's comic style has been a breakthrough in the history of film comedy. If I have argued earlier that film comedy tends to distance itself from enjoyment reducing contents, Woody Allen bases his films on such contents, sex being one of them. In his film Everything You Wanted to Know about Sex but Were Afraid to Ask (1972), Woody Allen directs some comic scenes: a shepherd who falls in love with a sheep; a television contest for choosing the week's king of perversion; that week the winner was Rabbi Haim, whose great desire was for a young girl to tie him with ropes and whip him while eating pork; a gigantic breast detached from its natural place and swelling to monstrous dimensions, until it reaches the height of a four storey building, moving, and threatening to suffocate anyone in its path.

More specifically, the first scene, where the shepherd falls in love with his sheep, represents an extreme deviation from the norm of the relationship between humans and animals. The audience may be negatively affected by the content which relates to prohibitions, inhibitions and sexual confusion. The masochist Rabbi represents two types of prohibition: one is his pervasive masochistic nature and the other -a violation of a religious prohibition for both Jews and Muslims- eating pork. The third scene depicts a deformed breast which rolls in the city and suffocates anyone in its way. Death and deformation, even when perceived as comic, contain an element which disrupts the existing order and may affect the viewers.

Each of the above comic situations involves aspects that contradict each other, one arousing enjoyment and laughter based on the comic structure of the situation, and the other arousing stress or anxiety generated from the presentation and function of the Enjoyment 
Reducer. In the last part of Bananas (1971), Woody Allen creates a series of bedroom situations. He has sex with his wife in front of media representatives, indeed, between the covers, but he is interviewed while having sex. The sexual act is referred to as a boxing arena. Allen goes to bed making the gestures of a boxer and the reporter interviews him "at the arena". A mixture of laughter and embarrassment is also found in Woody Allen's Annie Hall (1977), where he shares his sexual experiences, and especially his sexual problems, with the viewers. It should be noted that Allen's feeble and ridiculous figure serves as a moderating influence for the Enjoyment Reducers and leaves much room for enjoyment.

\subsection{Humour and drunkenness}

Drunkenness is accepted with leniency and sometimes with great pleasure. Although it supposedly represents disruption of the order, it is in the end temporary and manageable. The drunken person will sober up and will return to normal behaviour. The temporary state of drunkenness neutralises the motif of disquiet to a great extent and leaves much room for enjoying the comic situation. Chaplin used drunkenness as a comic motif in some of his films, where it is presented in a naïve, clown-like manner (A Night Out 1915; The Idle Class 1921; One A.M 1921; City Lights 1930).

\subsection{Humour and physical deformation}

Physical deformation constitutes an Enjoyment Reducer, which classical film comedy tends not to use too often, as it represents an extreme, irreversible disruption of order. However, as Aristotle claims in his Poetics, some deformations are acceptable and stimulate laughter (Aristotle 1967: 29-41).

Squint, which is perceived to be comic, is the exception. It is considered a light physical deformation and hence is less of an Enjoyment Reducer. Therefore, it is often used in comedy film. Following are few examples: Marty Feldman plays the role of the cross-eyed hunchback in Mel Brooks' Young Frankenstein (1974). It has to be noted that Feldman is inherently cross-eyed. Ben Turpin, too, is naturally cross-eyed and acted in many comic films. Furthermore, Tati created a comic scene based on the cross-eyed principle. A person wishes to place a wedge in the ground and asks Tati to hold the wedge. Tati agrees to help, but the person uses his hammer to hit the adjacent wedge. Tati looks at him and we see the man is cross-eyed (Jour de Fête 1949). A similar situation is depicted in the film La Grande Vadrouille (1966), featuring Louis de Funès: a German soldier has to unload a specific wine barrel from the wagon, but, instead, he unloads a different one, which is used for hiding the British pilot from the Germans. Here, too, the mistake was made because the German soldier was cross-eyed.

One of the funniest skits in TV comedy has to do with a vision disorder, this time, not a squint, but rather diplopia (double vision). It is from Monty Python's Flying Circus (1983), where John Cleese organises an expedition to Mount Kilimanjaro. His problem is that he sees everything twice. A mountaineer comes to find out about the expedition and Cleese addresses him as two persons rather than one. He also presents the expedition's goal as climbing both peaks of Mount Kilimanjaro. 


\subsection{Humour and danger}

An additional group of comic situations which include Enjoyment Reducers is that where the comic figure is in circumstances which might pose threats to his or her physical safety. This type of humour was highly popular during the silent film era, when comedians performed a great part of the acrobatic exercises on their own, without using stuntmen.

Harold Lloyd was one of the most prolific creators of comic situations of this kind. In his film Safety Last (1923), he climbs a skyscraper, and the climb is accompanied by funny incidents, among which he nearly falls, but is saved at the last moment by desperately clinging to the hands of the skyscraper's clock. When the clock is torn from the wall, Lloyd remains dangling on one of the clock's springs at twelve storeys above the street. In a different scene, he enters a flat through the window. Workers in the flat take a beam out of the flat, which hits Lloyd and pushes him out the window.

Buster Keaton creates a long line of comic situations which include the motif of the danger of death. In his film Our Hospitality (1923), he is dangling on a branch carried by a river and is stuck over a high waterfall. The branch may fall at any moment. When he rests on it and it starts moving, the audience laughs, naturally, but at the same time they fear for his fate.

Harry Langdon, in an encounter with a herd of sheep, faces a tall wooden fence blocking his way. He decides to climb over it to the other side. He does not realise the fence is on a cliff over a precipice. The audience laughs, but the possibility that Langdon might fall into the precipice generates anxiety (Tramp, Tramp, Tramp 1926).

Charlie Chaplin skates in a department store. He does it blindfold. While skating, he reaches the surface edge and might fall to the bottom floor. The audience laughs, and yet is apprehensive (Modern Times 1936). Charlie's cabin is carried by the wind and comes to rest on the lips of a chasm. Charlie is inside the cabin and is not aware of what is happening. His every move tilts the cabin in the direction of the chasm. The audience laughs, but the danger motif becomes more intense and with it the audience's anxiety (The Gold Rush 1925).

All these comic situations generate high anxiety level that is relieved by the laughter that follows. These situations include Enjoyment Reducers, which are all controlled by the operating comic figures as well as by the knowledge that all will end well.

A convention that is well known in the circus was embraced by comedy films: it is possible to hit a head with an object, and kick a behind; to throw a cream pie at someone's face and sometimes slam the door in his face. A comic situation which includes a bump or blow to another part of the body may deviate from convention and arouse anxiety. It appears the viewers become anxious in situations where there is a danger of injury or physical harm to a person. Many comedians have "sinned" with this type of humour. Following are a few examples: Laurel and Hardy work as assistants in the circus arena. Hardy stands on a high scaffold; Laurel operates the canon and the shell hits Hardy's back. As a result, the scaffold collapses with Hardy (The Chimp 1932). The situation is comic, but the shot landing on Hardy's back causes concern that he may have been severely hurt. The viewers can feel the hit on their own backs. We must bear in mind that watching a movie or a play is not passive viewing. We experience the events in our bodies and souls.

In two of his films (Laughing Gas 1914; The Masquerader 1914), Chaplin throws stones at people hurting various body parts. In other films, he steps over people, throws different objects at them and kicks their bodies (Caught in the Rain 1914; His New Profession 1914; Shanghaied 1915; His New Job 1915). In his film The Property Man (1914), Chaplin forces a weak old man to carry a heavy case for him. The case falls on the old man, who asks 
for Chaplin's help. Chaplin then climbs a ladder and tries to pull the man from under it. At the same time, he kicks the old man in his body and face. In another film (In the Park 1915), Chaplin throws a burning cigarette stub into a baby carriage and then falls into it. All these comic situations include danger as an Enjoyment Reducer and may disrupt the viewers' pleasure with the comic situations in particular and the film in general.

In contrast, there are comic situations which include physical injuries to the point of killing a person, and yet, they are accepted with great pleasure. This happens when the injured party is the enemy or the antagonist representing evil. Therefore, the audience is not offended by the comic situation. On the contrary, enjoyment derived from doing away with the enemy enhances the pleasure derived from the comic situation, for example in La Grande Vadrouille (1966). The Nazi soldier rides a motorcycle chasing a truck driven by Louis de Funès and his friend Bourvil. He speeds while his eyes follow the white line in the centre of the road. At a certain place the white line deviates from the centre to the side of the road (the worker marking the line is resting at the side of the road), and so the motorcyclist following the white line falls off a cliff. Louis de Funès and Bourvil are saved. In this comic situation, the motorcyclist represents evil, and so his possible death serves as a source of relief and enjoyment.

\subsection{Humour and harm to flora and fauna}

There are comic circumstances based on harm to flora and fauna, and these situations include Enjoyment Reducers. In La Zizanie (1978), Louis de Funès is interested in extending his production area. He intends to do that at the expense of his wife's greenhouse, to which she naturally objects. He inserts cold air into the greenhouse, and the plants freeze. The water in the fish tank (aquarium) also freezes, with a fish trapped in the ice. Later, to intensify this unusual situation, the fish tank is erroneously placed on the stove. The water is boiling, including the fish. This scene's comic quality is compromised as a result of the cruelty it portrays. The screenwriter and the director were crude when they created the scene. They did not consider the Enjoyment Reducers in the comic situation, and thus hindered the humour and the pleasure.

You may eat a fish, roast it, remove its skin and so forth to enjoy a good meal, but to kill a fish or any other animal in order to construct a comic situation is not accepted with enjoyment. The frozen garden, the plants and flowers that have been destroyed also constitute Enjoyment Reducers. Chopping wood for heating or for industrial use is acceptable. Harming the vegetation and destroying it when there is no need, even when it means creating a comic situation, is less acceptable.

In their film Swiss Miss (1938), Laurel and Hardy are hanging on a rope bridge over a gorge and meet a gorilla that scares them. Eventually, the gorilla falls to the gorge. It is clear that the gorilla is dead. This can seriously reduce the viewers' enjoyment. Towards the end of the film, the director brings back the gorilla, which is bandaged and leaning on a crutch. This makes things easier and may improve the viewer's mood. However, the compensation for the failed enjoyment created when the gorilla falls is only partial.

Comic situations of this sort can be created differently. In Buster Keaton's film The Balloonatic (1923), a bear suddenly appears in front of him. Keaton is trying to chase the bear away by using the butt of his rifle and a shot is fired backwards. It turns out that there was another bear behind Keaton's back, trying to attack him. The bear was killed. The bear's death does not harm the comic experience, because it puts Keaton's life in danger. To further 
minimise the possibility of damaging the enjoyment, Keaton shoots the bear inadvertently and indirectly.

There is another example of the appropriate use of killing an animal in Chaplin's film The Gold Rush (1925). Charlie and his friend killed a bear to satisfy their hunger. In this case, thinking that death is not something you want to see in a comic situation, the audience sees Chaplin and his friend eating, but they see neither the actual killing nor the dead bear.

\section{Humour and enjoyment enhancers}

Religion and the religious officials are often subject to humorous situations. In 1979, the Monty Python Company aroused a great deal of protest when the film Life of Brian appeared, mocking the religious perception of Jesus and his life. Nevertheless, many comedians made use of these materials but usually with more sensitivity. For example, Charlie Chaplin in his motion picture The Pilgrim (1923) enters a chapel and conducts prayers in a humorous fashion. In the chapel there are no outward signs identifying it as a church or Christian house of worship. Louis de Funès, in the film Les Aventure de Rabbi Jacob (1973) escapes his pursuers disguised as a Jewish Rabbi. He enters a synagogue, approaches the Torah Scroll and murmurs a few unintelligible words as if he were immersed in prayer. This behaviour can be accepted with understanding and pleasure because the situation warrants it.

There are factors which increase the viewer's enjoyment of comic situations. The following are five such factors:

A. Good mood. When we are aware of a good thing which is going to happen to us, we smile or laugh and enter a state of good mood before the actual event occurs (Strack et al. 1988; Foley et al. 2002). Knowing that you are about to watch a funny film or play, or knowing the clown is about to enter the circus arena increases the sense of early enjoyment before the actual viewing. When a person is in a good mood, he or she responds to events in a more positive manner. This is also true of comic situations.

B. Convention. Prior knowledge that what is happening is not real. Viewers know that the gun does not really kill and certainly not the good people. They know that a hammer blow to the head will not cause any real damage other than slight blurriness and that a car crash will damage the car, but not the people in it (see Aristotle 1967: 41). These are some of the conventions of comedy and the viewers are aware of them. The circus clown further emphasises the sense of being harmless. He puts on a red nose and makeup with a big smile, huge shoes and baggy pants, to tell viewers "All you see from this moment on is not serious, because I'm not an ordinary person; I'm a clown". From that moment everything that may happen -a fall, a kick in the butt, a hammer blow to the head-will be perceived as harmless and comic. The viewer is ready to go where the clown leads, knowing that nothing bad will happen. Therefore the influence of Enjoyment Reducers will be marginal and enjoyment of the comic situations will prevail. This is especially emphasised in animated cartoons. The cat and mouse may fall off a cliff and get hit by a steamroller, but they immediately return to their full strength as if nothing had happened. A dynamite bomb may explode under the buttocks of Mickey Mouse or Pluto, and although they break into parts, we know they will return reassembled and whole. Death does not exist in comic cartoons. This convention enhances the viewers' enjoyment. 
C. The comic figure. "The mere presence of a familiar comic character gives the audience a pleasant expectation of humour to come. This is all-important in performance comedy, which relies heavily on the social dynamics within the audience and between the audience and the performers" (Triezenberg 2004). We know that the comic figure in films, theatre or the circus cannot do anything that is really bad, as it is clear to us that nothing bad could happen to the comic figure. Therefore, the viewer is open to almost everything a comic figure does and is rather forgiving and even identifies with the figure's actions. The comic figure is a means through which the viewers can realise actions they cannot perform themselves because of personality inhibitions and social prohibitions. The "viewer's clown" connects to the clown on the screen, and together, they have an enjoyable experience that makes the viewer laugh and feel relieved. When Chaplin disrupts the social order, the viewer's "personal clown" does that as well, and this time there is no way he will be punished for it. The viewer tries to neutralise any negative feelings that may impair what is experienced through the comic character and is fully engaged with his/her enjoyment.

D. Clown use of accessories. To remove the frightening features from accessories such as knives, guns, razors and canons, circus clowns alter the accessories radically by making them look ridiculous. For instance, they use a gigantic razor or scissors, which are no longer frightening, but are rather funny. To further reduce anxiety, accessories are made of plastic or wood rather than metal, thus doing away with another threatening element. For example, in Sherlock Junior (1924), Keaton uses a miniature canon. Despite the danger of being hurt, the size of the canon reduces the anxiety factor. In Behind the Screen (1916), Chaplin carries a decorative post and bumps into people, the camera and lamps. The post is made of carton and so the viewers can afford to laugh and enjoy the scene, knowing no serious damage can be caused, except some mess.

E. The happy ending. Each work, including comic works, has an ending. Naturally, the viewers want the comedy to end well. Comedy in general and comedy films in particular are largely optimistic. More generally, tragedy sees life as individual struggle, while comedy sees it as social adventure (Morreall 1998). The happy ending of the comedy plot is self-evident. A happy ending is an enjoyment enhancing factor and comedy writers are well aware of this. Viewers enjoy watching a comic film that includes a successful romantic relationship. Such a happily ending relationship between a man and a woman is welcomed by the audience (Harrod 2013). This enjoyment is added to the viewers' delight in the comic situations and both increase the level of general enjoyment. In other words, successful romantic content work as Enjoyment Enhancer; for instance, the Marx Brothers' A Night at the Opera (1935), Chaplin's The Gold Rush (1925), Keaton's The General (1927), Lubitsch's The Merry Widow (1934) and The Shop around the Corner (1940).

\section{Conclusion}

Enjoyment Reducers constitute an integral part of any comic situation in a film or a show. The level of their influence on the viewers depends on both the content of the comic situations and the viewers. Comedy is not detached from the viewer's inner and outer worlds, personality structure, basic beliefs, culture and values (Zillmann 2000; Kuipers 2006). The viewer entering the movie theatre watches the film through the prism of his/her emotional burden, beliefs, values and taboos (see Triezenberg 2004) One of the main functions of 
comedy is to make the viewer laugh and experience as much enjoyment as possible. Enjoyment may derive from both the comic structure of the unusual situation and its content.

There is a connection between enjoyment and a happy ending. The happier the end of the comic film or show the greater the viewer's enjoyment. Research conducted in Germany on the wave of comedy films that began in the early 1990s, after the reunification of Germany, shows that the films all have a happy ending in response to the psychological needs of the population to relieve existential fears experienced during the same period (Halle 2000).

There appears to be room for further sociological and psychological research on the cultural and personal differences relating to humour reducers and their meaning for both the creator and the comedy viewer.

\section{References}

Aristotle (1967). Poetics. Tel Aviv: Hakibuts Hameuhad \& Tel Aviv University. [in Hebrew] Calder, N. (1973). Mohah Ha Adam [The Man's Mind]. Tel Aviv: Am Oved.

Cazeneuve, J. (1971). Sociologie du Rire. Paris: P.U.F.

Foley, E., Matheis, R. \& Schaefer, C. 2002. 'Effect of forced laughter on mood'. Psychological Reports 90 (1), p. 184.

Forabosco, G. (1992). 'Cognitive aspects of the humor process: The concept of incongruity'. Humor: International Journal of Humor Research 5 (1-2), pp. 45-68.

Freud, S. (1965). Totem et Tabou. Paris: Payot.

Hall, A. (2007). 'The social implications of enjoyment of different types of music, movies and television programming'. Western Journal of Communication 71 (4), pp. 259-271.

Halle, R. (2000). "'Happy ends" to crises of heterosexual desire: Toward a social psychology of recent German comedies'. Camera Obscura 15 (44), pp. 1-39.

Harrod, M. (2013). 'Sweet nothings? Imagining the inexpressible in contemporary French romantic comedy'. Studies in French Cinema 13 (2), pp. 171-187.

Hay, J. (2001). 'The pragmatics of humor support'. Humor: International Journal of Humor Research 14 (1), pp. 55-82.

Israeli General Encyclopaedia (1990). 'Taboo'. Vol. 2, p. 125. [in Hebrew]

Katz, E., Gurevitch, M. \& Haas, H. (1973). 'On the use of mass media for important things'. American Sociological Review 38, pp. 164-181.

Katz, E., Blumler, J. G. \& Gurevitch, M. (1974). 'Utilisation of mass communication by the individual', in Blumler, J. G. \& Katz, E. (eds.), The Uses of Mass Communications: Current Perspectives on Gratifications Research, Beverly Hills, CA: Sage, pp. 19-32.

Kuipers, G. (2006). 'Television and taste hierarchy: The case of Dutch television comedy'. Media, Culture \& Society 28 (3), pp. 359-378.

Kuiper, N. A., Martin, R. A., \& Olinger, L. G. (1993). 'Coping humor, stress, and cognitive appraisals'. Canadian Journal of Behavioural Science 25 (1), pp. 81-96.

Lallo, C. (1949). Esthetique du Rire. Paris: Flammarion.

Lothane, Z. (2008). 'The uses of humour in life, neurosis and in psychotherapy: Part 2'. International Forum of Psychoanalysis 17 (4), pp. 232-239.

Medhurst, A. (2007). 'Heart of farce: Almodóvar's comic complexities'. New Cinemas: Journal of Contemporary Film 5 (2), pp. 127-137.

Morreall, J. (1998). 'The comic and tragic visions of life'. Humor: International Journal of Humor Research 11 (4), pp. 333-355. 
Morreall, J. (2009). Comic Relief: A Comprehensive Philosophy of Humor. Chichester: Willey-Blackwell.

Pop, D. (2012). 'Dark humour and the imaginary of the new Romanian filmmakers'. Caietele Echinox 23, pp. 259-266.

Raskin, V. (1985). Semantic Mechanisms of Humor. Dordrecht: D. Reidel.

Ravi, S. (2008). 'Tamil identity and diasporic desire in a Kollywood comedy: Nala Damayanti'. South Asian Popular Culture 6 (1), pp. 45-56.

Reiss, S. \& Wiltz, J. (2004). 'Why people watch reality TV'. Media Psychology 6 (4), pp. 363-378.

Shultz, T. R. (1972). 'The role of incongruity and resolution in children's appreciation of cartoon humor'. Journal of Experimental Child Psychology 13 (2), pp. 456-477.

Sover, A. 2009. Humor bedarko shel haadam hatzohek [Humour: The path way to human laughter]. Jerusalem: Carmel.

Spinoza, B. (1967 [1677]). Torat Hamidot [Ethics]. Ramat-Gan: Masada.

Swabey, M. T. (1970). Comic Laughter: A Philosophical Essay. Hamden, CT.: Archon Books.

Strack, F., Martin, L. L. \& Stepper, S. (1988). 'Inhibiting and facilitating conditions of the human smile: A nonobtrusive test of the facial feedback hypothesis'. Journal of Personality and Social Psychology 54 (5), pp. 768-777.

Tamborini, R., Bowman, N. D., Eden, A., Grizzard M. \& Organ, A. (2010). 'Defining media enjoyment as the satisfaction of intrinsic needs'. Journal of Communication 60 (4), pp. 758-777.

Triezenberg, K. (2004). 'Humor enhancers in the study of humorous literature'. Humor: International Journal of Humor Research 17 (4), pp. 411-419.

Waldron, D. (2006). 'New clothes for temporary transvestites?: Sexuality, cross-dressing and passing in the contemporary French film comedy'. Modern \& Contemporary France, 14 (3), pp. 347-361.

Zillmann, D. (2000). 'Humor and comedy', in Zillmann, D. \& Vorderer, P. (eds.), Media Entertainment: The Psychology of its Appeal, Mahwah, NJ: Lawrence Erlbaum Associates, pp. 37-57.

\section{Appendix: List of films in alphabetical order including the main comedians or directors}

Annie Hall, 1977: Woody Allen

A Night at the Opera, 1935: Marx Brothers

A Night Out, 1915: Charles Chaplin

Bananas, 1971: Woody Allen

Behind the Screen, 1916: Charles Chaplin

Caught in the Rain, 1914: Charles Chaplin

City Lights, 1930: Charles Chaplin

Everything You Always Wanted to Know about Sex but Were Afraid to Ask, 1972: Woody Allen

High Anxiety, 1977: Mel Brooks

His New Job, 1915: Charles Chaplin

His New Profession, 1914: Charles Chaplin

In the Park, 1915: Charles Chaplin

Jour de Fête, 1949: Tati Jacques 
Laughing Gas, 1914: Charles Chaplin

La Grande Vadrouille, 1966: Louis de Funès \& Bourvil

Les Aventure de Rabbi Jacob, 1973: Louis de Funès

La Zizanie, 1978: Louis de Funès

Limelight, 1952: Charles Chaplin

Modern Times, 1936: Charles Chaplin

Monty Python's Flying Circus, TV Series, 1969-1971: Monty Python

Monty Python's Life of Brian, 1979: Monty Python

Monty Python's Meaning of Life, 1983: Monty Python

One A.M, 1916: Charles Chaplin

Our Hospitality, 1923: Buster Keaton

Safety Last, 1923: Harold Lloyd

Shanghaied, 1915: Charles Chaplin

Sherlock Junior, 1924: Buster Keaton

Silent Movie, 1976: Mel Brooks

Swiss Miss, 1938: Laurel \& Hardy

The Adventure of Sherlock Holmes' Smarter Brother, 1975: Gene Wilder

The Balloonatic, 1923: Buster Keaton

The Chimp, 1932: Laurel \& Hardy

The General, 1927: Buster Keaton

The Gold Rush, 1925: Charles Chaplin

The Idle Class, 1921: Charles Chaplin

The Masquerader, 1914: Charles Chaplin

The Merry Widow, 1934: Ernst Lubitch

The Pilgrim, 1923: Charles Chaplin

The Shop around the Corner, 1940: Ernst Lubitch

The Property Man, 1914: Charles Chaplin

The Twelve Chairs, 1970: Mel Brooks

Tramp, Tramp, Tramp, 1926: Harry Langdon

Young Frankenstein, 1974: Mel Brooks 